DE DE GRUYTER OPEN
Journal of Intercultural Management

Vol. 7, No. 3, September 2015, pp. 39-51

DOI 10.1515/joim-2015-0020

Agnieszka Fornalczyk ${ }^{7}$

University of Wrocław

Jagoda Stompór-Świderska ${ }^{8}$

University of Wrocław

Magdalena Ślazyk-Sobol ${ }^{9}$

University of Wrocław

\title{
Age Management within Organizations - Employees' Perceptions of the Phenomenon - Research Report
}

\begin{abstract}
This article discusses the issue of age management in organizations and presents research results concerning workers' perceptions of the phenomenon. The aim of the research was to study the perceptions of Polish employees of various professional fields, check employees' level of knowledge of the age management issue, determine the variables differentiating this knowledge and verify whether employees consider age management to be useful and how they perceive experienced workers.

The first part of the article presents concepts explaining what age management is in the context of demographic changes in European societies. Age management is a term encompassing a range of methods aiming at the possibly most effective use of human capital in organizations, irrespective of employees' age, so that their work is efficient, profitable for the company as well as satisfying for the workers themselves. Strategies referring to age management should consider the perspectives of the company, employee, job market policy and demographic and economic situation conditions. In the later part
\end{abstract}

\footnotetext{
${ }^{7}$ agnieszka.fornalczyk@wp.pl

8 jagoda.stompor-swiderska@uwr.edu.pl

${ }^{9}$ m.slazyk-sobol@psychologia.uni.wroc.pl
} 
of this article, the authors present the results of exploratory research into the level of knowledge of age management, the way it is perceived in organizations around Poland, mostly in international corporations. The research included employees of business and budget sectors. Respondents answered questionnaire questions by estimating, on the Likert scale, how they assess age management measures taken in their workplace, the need to use experienced workers' potential, etc. In the authors' opinion, because of the importance of the problem of efficient personnel management and promoting and applying age management programs, it is necessary for both employees and managers to have awareness, knowledge and positive attitude towards methods activating the potential of employees from various age ranges.

Key words: age management, experienced employee, use of human capital, perceptions of age management phenomenon.

\section{Introduction}

The phenomenon of population ageing has been observed in many European countries for many years [Kowaleski, Majdzińska 2012]. The process is determined by various factors including life span extension, drop in the number of children per family and related birth rate decrease. Population of people over 60 years of age is estimated to have increased 3 times by 2100 [Bieling, Stock, Dorozalla 2015, p. 6, Office for National Statistics, 2012, p. 3]. The most visible increase in this age group will be observed in developing countries, also in Poland. European population is the oldest in the world as people over 40 constitute over a half of the population [World Population Ageing: 1950-2050, pp. 22-23]. Social awareness of population ageing has been increasing. Therefore, future competitiveness of companies and entire economies will largely depend on efficiency and productivity of older employees as well as effective use of their skills [Fabisiak, Prokurat 2012, p. 84]. For many countries it is a priority to increase older people's professional activity, and Age Management is an important factor in achieving this aim [Auer \& Fortunly 2000, p. 5].

The abovementioned phenomena significantly determine changes in the structure and size of workforce [Kulik, Ryan, Harper, George 2014, p. 929]. Contemporary workers come from four generations and cover over 50 years of a man's lifetime. In organizations there are employees of just 20 years of age as well as those aged over 70 . In many organizations it is vital for three generations to be able to cooperate [Böhm, Kunze, 2014, p. 668]. Organizations face the necessity to exploit age diversity effectively. It requires understanding the processes both on macro and microeconomic levels, knowledge of team building, acknowledging different needs of employees of varied ages and their differing ways of functioning. The notion of the social categorization perspective shows that people prefer to work with colleagues similar to themselves [Williams, O'Reilly 1998]. Creating teams of workers of different ages might lead to an increased number of conflicts in the workplace. It might lower the level of identifying with the organization, lower 
commitment level and result in lower efficiency in comparison with homogeneous work teams.

On the other hand, the concept of information perspective explains the positive impact of diversity on work results. The increase in efficiency within the diversified group is based on the assumption that employees working in varied groups (diversified demographically or in any other way) might be given a wider scope of tasks or have wider knowledge. In such a team, skills and abilities at the whole group's disposal are accumulated. What's more, the team's creativity increases leading to improved decision taking [Bell 2007].

Competent combination of personal and professional strengths of younger and older employees might help to achieve success and stimulate organization's development.

Current and predicted demographic changes present new challenges for employers in the area of human resources management and must not be ignored. In fact, it is a double challenge as it means attracting young talents and, at the same time, retaining older employees. In the light of these changes, organizations are required to revise their $\mathrm{HR}$ policies and practices. Diversity management, including age management, is a positive solution for the challenges. The possibility to create work environment in which varied age employees' potential is used skillfully is considered a competitive advantage of the organization [Čiutiené, Railaite 2013, p. 27]. Diversity management, in terms of age, involves planning and implementing organizational practices of managing workers of different age to maximize potential benefits of the diversity and minimize its potential downsides [Cox Jr 1994, p. 11]. Age management aims at attracting the best employees of all age ranges to work for the organization [Naegele \& Walker 2006, pp. 1-2]. It refers to recruitment, training and lifelong learning, career development, flexible working hours, health care and education, redeployment, retirement plans. It is a complex approach focusing on workers' entire life span and encompassing preventive and corrective measures [Naegele \& Walker 2006]. Other measures used by companies to retain older employees include team work promotion and cooperation programs to meet the needs of older workers and enable them to continue expanding their knowledge and skills. Such strategies are beneficial not only for the older employees but also give their younger colleagues the chance to improve their skills and increase efficiency and involvement [Albright \& Cluff 2005].

One of the factors that allow achieving high efficiency of all age groups is creating the climate for age management in the whole organization, unifying perceptions of diversity management policies, practices and procedures with reference to age. It is essential to create the belief that an employee's age is not a barrier to progress within organization. HR practices should be internally consistent and based on logical systems. Support should be given equally to all employees, irrespective of 
their age, to ensure access to training and further development for all age groups. In this way, organizations can ensure that all age groups possess required knowledge and skills to carry out their tasks properly and contribute to company efficiency.

Another significant factor in transparent HR policy should be to give all employees, irrespective of age, a chance to be promoted or redeployed. It is also beneficial to create organizational culture which takes into account age-friendly promotion of the value of all age groups' contributions and promoting integrationfocused managerial staff. Employers should be aware of age diversity in their organizations and take measures to strengthen the feeling of being a recognized member of organization, irrespective of age.

Of importance is also the role of social campaigns aiming at informing employers about the benefits of hiring staff of diversified age. They could help to decrease prejudice against older workers. Experience of age management and examples of good practice in this area frequently come from large organizations which are able to engage bigger funds in this activity. Good practice of age management has been set but it is not universal. There is a considerable gap between policy and practice. Organizations' employees should understand what age management is and what it aims at. This awareness is of significance in the context of shaping their attitudes to older employees and building commitment among organization staff.

\section{Research methodology}

The purpose of this research was to study age management perceptions of Polish employees from various industry sectors. To meet this objective, the following research questions were formulated:

- Do workers know what age management within organization is?

- Do developmental variables (age, sex) differentiate workers' knowledge of age management within organizations?

- Do demographic variables (education, work experience, place of work, position within organizational hierarchy, business sector) differentiate workers' knowledge of age management within organizations?

- Do workers' beliefs regarding the need to implement age management in organizations and attractiveness of experienced employees differ? If so, how?

- Do workers' beliefs regarding the use of knowledge and skills of experienced employees in their organizations differ? If so, how?

- Do workers' beliefs regarding opportunities to learn from experienced colleagues in their workplace differ? If so, how?

- What would workers like to learn from experienced colleagues in their workplace? Do developmental variables differentiate respondents' learning needs?

The research was primarily of exploratory nature, but also local (it was conducted in Lower Silesia).Therefore, research hypotheses were not formed. 
The research considered independent variables: developmental (age, sex), dependent variables: knowledge of the phenomenon of age management, perceptions and beliefs regarding age management in organizations. Demographic variables such as education, experience, position within organisational hierarchy, business sector were also studied.

The research was conducted anonymously, the procedure was standardized and used questionnaire method. To measure the variables selected for the research, the following tools were used:

1. Demographic data questionnaire (age, sex, education, experience and place of work, position within organisational hierarchy, business sector)

2. Age management phenomenon perception measurement questionnaire designed by the author for research purposes. It consists of 7 questions, including 2 ope$\mathrm{n}$-ended ones, allowing respondents to elaborate on what age management is as well as what they would like to learn from experienced workers in their organizations. The first open-ended question also allowed to verify whether employees accurately define the phenomenon of age management if they declared having (or not having) such knowledge. The closed questions also referred to the problem of the need to use age management programs in organizations, whether respondents have the opportunities to learn from experienced colleagues in their organizations (is their potential used) and whether the organizations employ workers who can be learned from. The last of the closed questions referred to perceiving experienced workers as attractive and desired in Polish companies and by Polish employers. Closed questions were answered by means of the $\mathrm{Li}$ kert scale. Respondents estimated their answers on the scale 0-5 from 'definitely unattractive' to 'definitely attractive' or 'definitely not useful' to 'definitely useful'. The analysis of open questions was done by 2 competent judges (psychologists) who categorized respondents' answers.

The research included 112 employees (women 60\% and men 40\%) employed in Lower Silesia organizations. Majority of research population had higher education $(88.4 \%)$. Secondary education respondents amounted to $11.6 \%$. The respondents represented the following sectors: IT $(43 \%)$, finance $(6 \%)$, production $(4.5 \%)$, trade and services (33\%), other (e.g. transport, education, energy - 13.5\%). The research group was diversified in terms of age and included respondents aged: under $25(41 \%)$, 26-40 (51\%), 41-60 (7\%) and one respondent (1\%) over 60. Employees with little professional experience (up to 3 years) constituted a big group of respondents $(38 \%)$, $42 \%$ of the respondents had experience of $4-10$ years, while $20 \%$ of the research population had many years of experience (11-26 years). 16\% of the respondents were employed at managerial positions, $31 \%$ were independent specialists and $53 \%$ were common organization workers. 


\section{Research results}

To answer the formulated research questions, data obtained in the research was analysed statistically. The empirical results referring to the respondents' knowledge of the phenomenon of age management show that half of the respondents (51\%) declare knowledge of the matter, $49 \%$ claim to lack knowledge of age management. Women significantly more often claimed to have the knowledge $(38 \%)$ than men (11\%), $(\chi 2=15,16, \mathrm{df}=1, \mathrm{p}<0.001)$. Respondents' age did not differentiate their beliefs about possessed knowledge $\left(\chi^{2}=1.83\right.$, df $\left.=3, \mathrm{p}<0.60\right)$, similarly to work experience $\left(\chi^{2}=4.07, \mathrm{df}=3, \mathrm{p}<0.25\right)$. When asked for a written explanation of what age management in organization is, only $12.5 \%$ of the respondents confirmed declared knowledge with actual one. $87,5 \%$ of the respondents inaccurately defined the phenomenon of age management in organization. In case of the second research question, referring to differentiating knowledge of age management by means of developmental variables, the obtained results unequivocally show that sex was the only significant variable $(\chi 2=3.87, \mathrm{df}=1, \mathrm{p}<0.05)$, while respondents' age was not of statistical significance $(\chi 2=3.35, \mathrm{df}=3, \mathrm{p}<0.34)$. Within the group of female respondents, only $7.5 \%$ had knowledge of what age management was, while $92.5 \%$ gave inaccurate answers (tab.1). Within the group of male respondents, $20 \%$ gave correct answers and $80 \%$ defined age management inaccurately.

Table 1. Percentage distribution for sex variable $(\mathrm{N}=112)$

\begin{tabular}{|l|l|l|l|}
\hline Sex & Know & Don't know & Total \\
\hline Women & $7.5(\%)$ & $92.5(\%)$ & $100(\%)$ \\
\hline Population & 5 & 62 & 67 \\
\hline Men & $20(\%)$ & $80(\%)$ & $100(\%)$ \\
\hline Population & 9 & 36 & 45 \\
\hline
\end{tabular}

Source: own description.

Demographic variables do not differentiate employees' knowledge of age management in organizations. Of no statistical significance are also education $\left(\chi^{2}\right.$ $=0.31 \mathrm{df}=1, p<0.58)$, work experience $\left(\chi^{2}=1.37 \mathrm{df}=3, p<0.71\right)$, position within organizational hierarchy $\left(\chi^{2}=2.70 \mathrm{df}=2, p<0.25\right)$ or sector $\left(\chi^{2}=8.56 \mathrm{df}=4, p<\right.$ $0.07)$.

With reference to the question regarding differences in employees' beliefs about the need to use age management in organizations and attractiveness of experienced workers for their employers, it must be noted that $52 \%$ of the respondents claimed that it is difficult to say whether it is necessary. $22 \%$ of the research population considered it rather useful and $24 \%$ saw it as very useful. No need or little importance of using age management was expressed by $2 \%$ of the respondents (fig. 1). 
Figure 1. Percentage distribution of respondents' answers related to the need of using age management in organizations $(\mathrm{N}=112)$

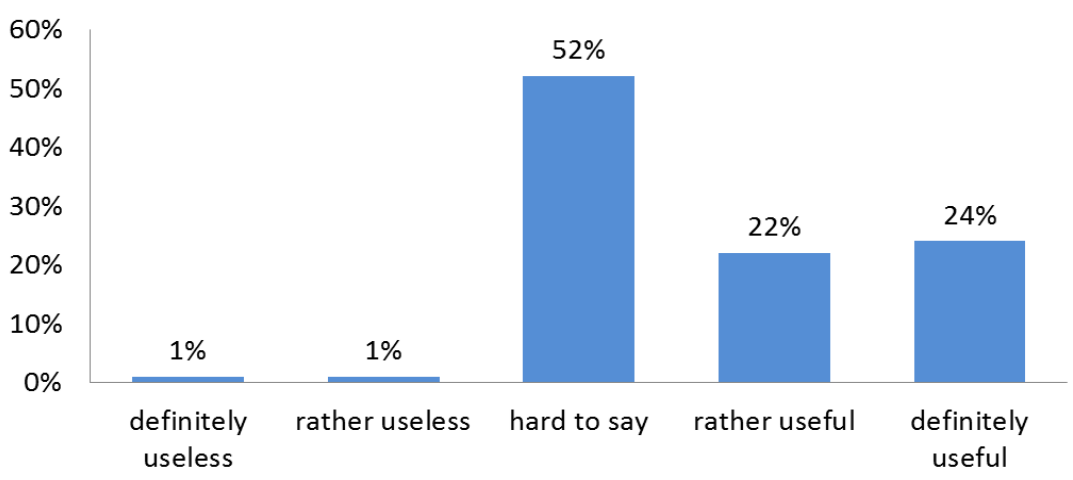

Source: own description.

Developmental variables, such as sex (U Mann-Whitney $=13.13$ for $\mathrm{Z}=-1.14$, $\mathrm{p}=0.26)$ and age $(\mathrm{H}=4.95$ for $\mathrm{df}=3, \mathrm{p}=0.18)$ did not differentiate respondents' beliefs regarding the need to use age management. Only a tendency was observed showing that the frequency of beliefs of the need to use age management in organizations increased alongside respondents' age. The opinion was shared by $39 \%$ of the respondents under 25 years of age, $49 \%$ respondents aged $26-40$ and $58 \%$ of those aged $41-60$. It is worth mentioning that the older the respondents, the less frequently they showed indecisiveness regarding the issue. The position within the organizational hierarchy was not a variable differentiating beliefs regarding the need to use age management programs in organizations.

Analyzing the perceptions regarding the attractiveness of experienced workers for their employers, the following conclusions were drawn: in total, $13 \%$ of the respondents believe that experienced workers are not very attractive for the employers, $29 \%$ find it difficult to answer the question, $38 \%$ believe them to be highly attractive and $20 \%$ think experienced workers are definitely attractive (fig. 2). 
Figure 2. Percentage distribution of respondents' answers regarding attractiveness of experienced workers for employers with reference to sex variable $(\mathrm{N}=112)$

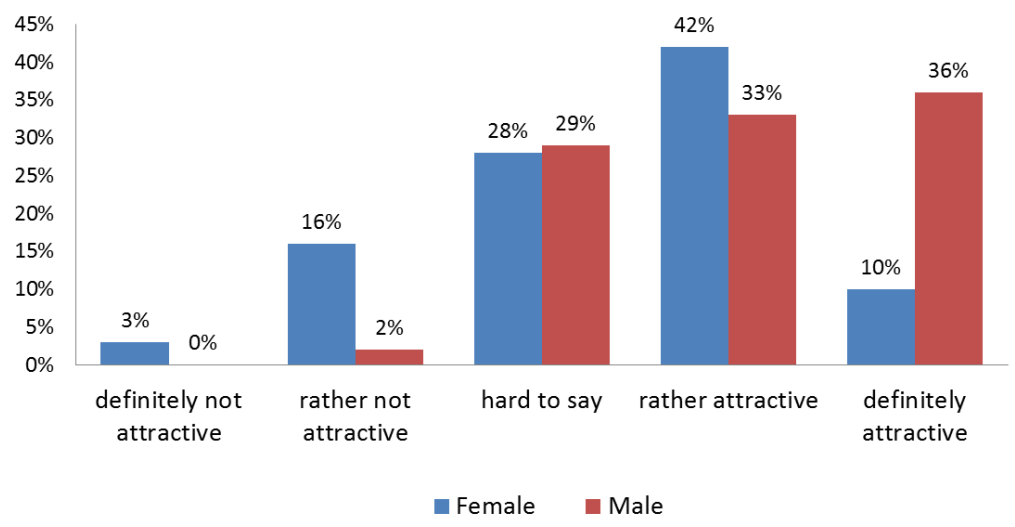

Source: own description.

Among developmental variables, only sex differentiated respondents' opinions on the attractiveness of experienced workers for employers (U Mann-Whitney=1009.0 for $\mathrm{Z}=-3.1014, \mathrm{p}=0.002)$. Women more often expressed their opinions about definite lack or low attractiveness of experienced employees for employers (19\%) in comparison with men $(2 \%)$. Male respondents more often claimed that experienced workers are desired by employers (69\% and 52\% respectively) (fig. 3).

Figure 3. Percentage distribution of respondents' answers regarding attractiveness of experienced workers for employers with reference to sex variable $(\mathrm{N}=112)$

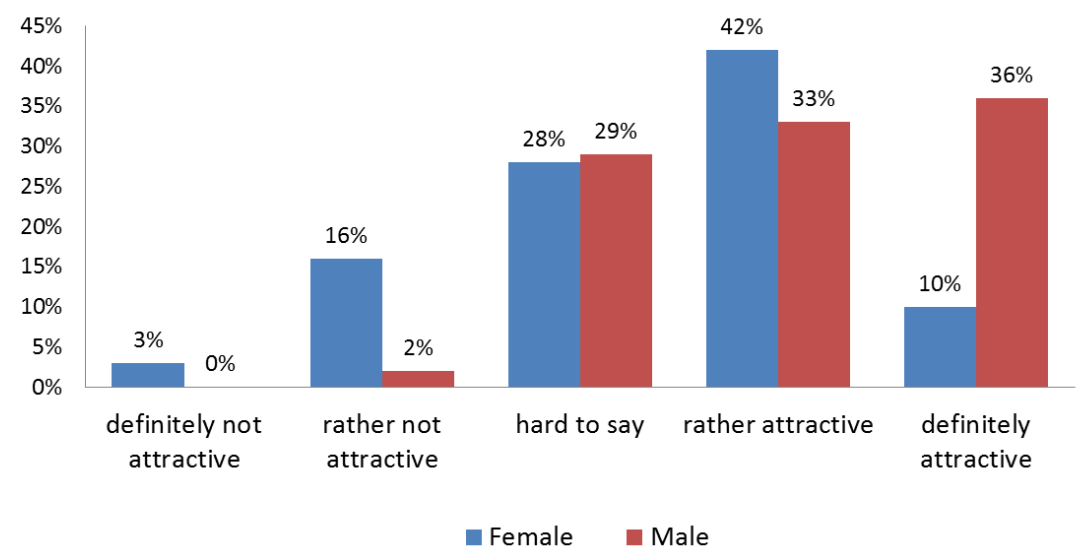

Source: own description. 
Age was not a statistically significant variable for beliefs regarding attractiveness of experienced workers for employers $(\mathrm{H}=3.06, \mathrm{df}=3, \mathrm{p}=0.38)$.

With reference to the next research question, regarding the use of knowledge and skills of experienced employees in their workplace, $38 \%$ of the respondents claimed that their potential is unused, $9 \%$ had no opinion on the issue and $53 \%$ believed that employers rather or definitely use the potential of their experienced colleagues (fig. 4).

Figure 4. Percentage distribution of respondents' answers regarding the use of experienced workers' potential in their workplace $(\mathrm{N}=112)$

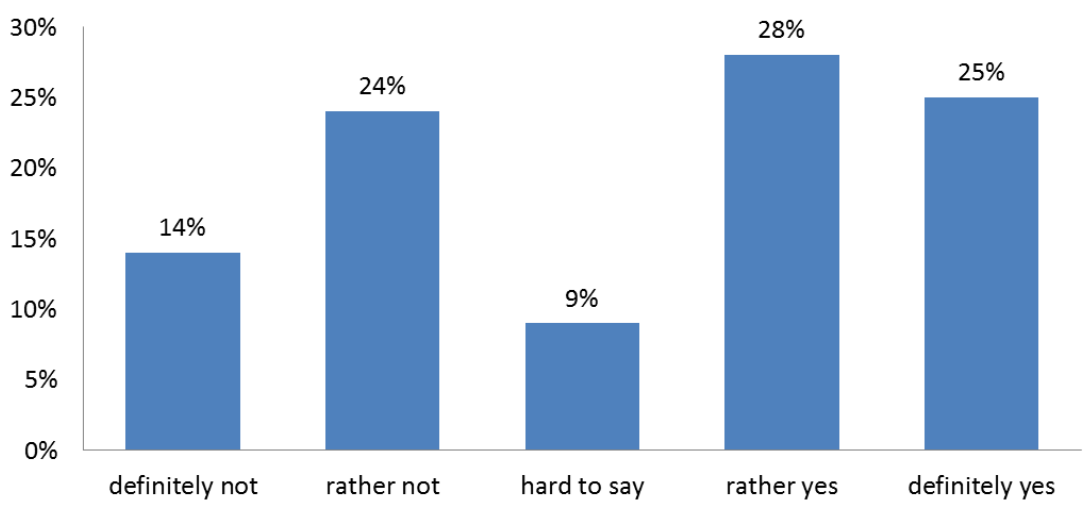

Source: own description.

Research results showed that answers varied between the two sex groups $(\mathrm{U}$ Mann-Whitney $=659.50$ for $\mathrm{Z}=-5.1714, \mathrm{p}=0.00) .55 \%$ of women claimed that employers definitely do not use or rather don't use the potential of experienced employees. In comparison, only $13 \%$ of male respondents expressed the same opinion. In male respondents' group, the majority (83\%) thought that employers rather or definitely use the knowledge and skills of experienced workers. Only 4\% of this group's respondents had no opinion on the issue. Positive opinions on the use of older employees' knowledge and experience in their workplace were expressed by $33 \%$ of women, while $12 \%$ found it difficult to say. Age was not a differentiating factor in respondents' answers regarding the above $(\mathrm{H}=3,26, \mathrm{df}=4, \mathrm{p}=0,51)$.

The last two questions referred to the opportunities to learn from experienced colleagues in their organizations. Obtained results show that $86 \%$ of the research population believe to have such opportunities, while $14 \%$ expressed no such opportunities for acquiring knowledge. Among the studied developmental variables, only sex shows to differentiate respondents' opinions $(\chi 2=5.95, \mathrm{df}=1, \mathrm{p}<0.05)$. 
Men significantly more often signalled the opportunity to learn from experienced colleagues, in comparison with women ( $96 \%$ and $79 \%$ respectively).

Obtained statistics show a generally high percentage of employees who have colleagues they can learn knowledge and efficient behaviour patterns from. Among the most frequently mentioned categories were specialist professional knowledge and professional skills (45\%), problem solving and handling difficult situations $(17 \%)$, work time management $(7 \%)$, people management (6\%), general skills $(5 \%)$ and other. Developmental variables were found not to differentiate significantly the areas employees wished to improve. Considering respondents' age, a trend was observed showing that young employees (under 25) most frequently wanted to acquire professional knowledge and skills $(56.5 \%)$ and learn problem solving skills $(17 \%)$. The need to learn professional competences $(35 \%)$ and handling difficult situations $(16 \%)$ were also observed among employees aged 25-40. Employees from $41-60$ age range expressed the need to learn professional skills ( $37 \%$ ) but also effective work time management (37.5\%). In this age group, it was also important for the employees to learn problem solving skills and handling difficult situations skills from the strategic perspective $(25 \%)$.

Demographic variables selected for this research do not differentiate respondents' answers in the context of needs related to learning from experienced colleagues.

\section{Discussion and conclusions}

In line with the assumptions presented in this article, age management should realize important aims of job market policy, including effective use of human resources, by considering the needs and potential of employees from various age groups or by increasing professional activity among people in their late adulthood (over 60) [Walker 1997, Naegele, Walker 2006]. Despite the fact that the issue of age management is widely promoted in the media or is the subject of numerous studies, research and discussions, the results obtained by the authors of this article show relatively poor knowledge of the matter. Half of the employees in the research declared lack of knowledge of the phenomenon of age management in organizations. Verifying the actual amount of possessed information provided results which show that as much as $87 \%$ of the research population do not know what age management is.

Considering the fact that awareness and knowledge of individuals in this area are significant cognitive components of attitudes [Ajzen 1991, Festinger 1995] which determine cooperation in age diversity conditions, obtained statistics are rather pessimistic. Moreover, $54 \%$ of the respondents do not see the need to use age management in organizations. Demographic and developmental variables do not differentiate employees' perceptions, although a tendency appears to view the need for age management in organizations more positively as the employees grow older. It should be noted that among employees in managerial positions only $16 \%$ 
considered age management necessary, although all respondents in this group had higher education. The result might surprise as company managers, irrespective of level, are responsible for people management including long-term personnel resources planning, development, adjusting employee attitudes and behavior or team work efficiency. The low level of awareness, knowledge and need to use age management observed among employees might result from their age. $92 \%$ of the respondents were young workers under the age of 25 and early adulthood workers under 40. Relatively young age of the employees means relatively short life experience perspective and might be decisive in terms of not considering or underestimating the factor of using experienced workers' competence. Young or young adulthood stage is characterized by self-focus, acquiring knowledge, experience, competence, position within the group, focus on satisfying own needs [Baltes, Smith 2008, Oleś 2011]. Orientation towards others, readiness to share experience and knowledge, effective cooperation, broad environment perception perspective typically appear at the stage of mid adulthood (over the age of 40). It should be added that in Polish companies the majority of employees are aged 25-45. Statistically, the number of this age employees is higher in Poland compared to other countries of the European Union [Liwiński, Sztanderska 2010]. Therefore, we do not observe a deficit in young staff or high supply of experienced workers on the Polish job market. It might significantly affect age management perceptions. The dominant number of employees from the young adulthood group (under 40) in Polish companies might lead to a decreased chance to use experience, knowledge and skills of older generations and, consequently, reduce the solutions' efficiency and creativity [Bell 2007, Nęcka 2012].

The belief expressed by $60 \%$ of the respondents convinced of high attractiveness of older generations of employees for their employers, is a significant indication of positive perceptions of experienced workers. Although women more frequently than men believed that experienced workers are not so highly desired in organizations or that their potential is not used in the workplace, in total, more respondents showed a positive perception of the phenomenon. Different perspectives of perceiving older employees' attractiveness by man and women might result from varied experience or the extent to which a negative stereotype of mid or late adulthood employees' affects their attitudes. This stereotype refers mostly to the supposed lower levels of flexibility, creativity, activity dynamics or intellectual capacity of older generations' individuals. The perspective described above might also derive from women's experience or perceptions of greater barriers in professional development of experienced workers or their potential not being used.

Discussing the issue of factors determining companies' readiness to use age management, it must be noted that, according to this research results, an undisputed majority of respondents $(86 \%)$ expressed the opportunity and willingness to learn 
from older colleagues. The motivation to learn manifested itself in respondents' pointing to precise needs concerning their development, e.g. acquiring knowledge and professional competence, problem solving or time management skills. Only $17 \%$ of the respondents did not indicate in which area they wish to learn from more experienced co-workers. The obtained results indicate employees' positive attitude towards cooperating with more experienced, in personal and professional terms, colleagues. This is of significance in the context of realizing current and future age management politics in enterprises.

Discussing the obtained empirical results, it is necessary to add that the authors of this research are not free from limitations resulting from the assumptions made for the research and methods used. One limitation is that of a small research sample which impedes conclusions' generalization. Presented research was a pilot study which is certainly worth repeating with a larger and more diversified sample, e.g. including a larger number of employees from mid and late adulthood populations. It is advisable for the research questionnaire to include more questions verifying beliefs concerning needs for and methods of using age management in organizations. It might also be relevant for future research to include measurement of social approval variable to test respondents' declarations rather than their actual behaviour in organizations. When planning future research, it is recommended to eliminate at least some of the mentioned limitations.

The summary of the above considerations might indicate implications for management practices. In the face of needs related to implementation or improvements in age management within organizations, it seems to be necessary to shape workers' attitudes in a way that would foster cooperation in age-diversity conditions. Molding employees' attitudes should include in fluencing the components of their cognition, emotions and behavior. Due to the low level of knowledge of age management phenomenon, it would be advisable to begin by impacting the cognitive sphere by providing education, building awareness of needs and benefits of using age management tools. It might also be important to create teams which are diversified in terms of age. This could facilitate experience exchange and mentoring as well as learning different perspectives of perceiving tasks and solving problems. Common experience might provide team members with support, fulfil their developmental needs and evoke positive emotions associated with cooperating with individuals from different age groups. Positive beliefs and emotions related to working in age-diversified teams should stimulate cooperation-oriented behavior and reduce conflict situations.

\section{References}

Albright W.D., Cluff G.A. (2005), A head of the curve: How MITRE recruits and retains older workers, "Journal of Organizational Excellence", vol. 24, issue 2, pp. 53-63. 
Auer P., Fortunly M. (2000), Ageing of the Labour Force in OECD Countries: Economic and Social Consequences, "Employment Paper", 2, International Labour Office, Geneva.

Baltes P.B., Smith J. (2008), The fascination of wisdom: Its nature, ontogeny, and function, "Perspectives on psychological science", vol. 3, pp. 56-64.

Bell S.T. (2007), Deep-level composition variables as predictors of team performance: A meta-analysis, "Journal of Applied Psychology", vol. 92, pp. 595-615.

Bieling G., Stock R.M., Dorozalla F. (2915), Coping with demographic change in job markets: How age diversity management contributes to organizational performance, Zeitschrift fuer Personalforschung, "German Journal of Research in Human Resource Management", vol. 29 issue 1, pp. $5-30$.

Böhm S.A., Kunze F., Bruch H. (2014), Spotlight on Age-Diversity Climate: The Impact of AgeInclusive HR Practices on Firm-Level, Outcomes, "Personnel Psychology", vol. 67, pp. 667-704.

Čiutienè R., Railaitè R. (2013), Employees Age Diversity Management, "Management of Organizations: Systematic Research”, issue 68, pp. 27-40.

Cox J.T. (1994), Cultural diversity in organizations: Theory, research and practice, San Francisco, CA: Berrett-Koehler Publishers.

Fabisiak J., Prokurat S. (2012), Age Management as a Tool for the Demographic Decline in the 21st Century: An Overview of its Characteristics, "Journal of Entrepreneurship, Management \& Innovation”, vol. 8, issue 4, pp. 83-96.

Kowaleski J., Majdzińska A. (2012), Starzenie sie populacji Krajów Unii Europejskiej- nieodległa przysztość i prognoza, „Studia Demograficzne”, no 161, pp. 57-80.

Kulik C.T., Ryan S., Harper S., George G. (2014), Aging populations and management', “Academy of Management Journal”, vol. 57(4), pp. 929-935.

Liwiński J., Sztanderska U. (2010), Zarz̨qdzanie wiekiem w prz̨edsiębiorstwie, Wydawnictwo Uniwersytetu Warszawskiego: PARP.

Naegele G., Walker A. (2006), A Guide to Good Practice in Age Management, European Foundation for the Improvement of Living and Working Conditions, Office for Official Publications of the European Communities, Luxembourg.

Nęcka E. (2012) Trening Twórçości, GWP.

Oleś P. (2011), Psychologia człowieka dorostego: ciagtość-zmiana-integracja, Warszawa, PWN.

Walker A. (1997), Combating Age Barriers in Employment. European Research Report, European Foundation for the Improvement of Living and Working Conditions, Dublin.

Williams K.Y., O'Reilly C.A. (1998), Demography and diversity in organizations: A review of 40 years of research [in:] Staw B.M., Sutton R.I. (ed.), Research in organizational behavior, vol. 20, pp. 77-140.

World Population Ageing: 1950-2050 http:/www.un.org/esa/population/publications/ worldageing19502050/pdf/90chapteriv.pdf.

Office for National Statistics (2012), Population ageing in the United Kingdom its constituent countries and the European Union, available at: www.ons.gov.uk/ons/dcp171776_258607.pdf (accessed 10 September 2015). 